\title{
Michał Biernacki
}

Uniwersytet Ekonomiczny we Wrocławiu

e-mail: michal.biernacki@ue.wroc.pl

\section{RACHUNEK KOSZTÓW ELCC A EKOMARKETING W DZIALALNOŚCI PRZEDSIĘBIORSTW}

\section{ELCC VS. ECOMARKETING IN COMPANIES' ACTIVITIES}

DOI: $10.15611 /$ pn.2017.480.01

JEL Classification: M41, Q560, M42

Streszczenie: W większości podmiotów wdrożony jest określony system rachunku kosztów. $\mathrm{Z}$ założenia ma być on dostosowany do potrzeb danego przedsiębiorstwa, umożliwiając podejmowanie decyzji przez kierownictwo na szczeblu zarówno operacyjnym, jak i strategicznym. Jednakże w praktyce wiele jednostek projektuje i wdraża go stosownie do bieżących, jak również przyszłych potrzeb, nie biorąc pod uwagę oczekiwań klientów pod względem ekologii, ochrony środowiska. Niniejszy artykuł ma na celu zaprezentowanie możliwości wykorzystania tzw. środowiskowego rachunku kosztów cyklu życia produktu (Environmental Life Cycle Costing - ELCC) w ekomarketingu, a także wyników badań ankietowych wśród przedsiębiorstw na terenie Dolnego Śląska związanych z takim połączeniem, które może stanowić wyraz ciągłego rozwoju nauk w ramach ochrony środowiska. Dzięki wdrożeniu ELCC można uzyskać bazę informacyjną o kosztach i przychodach powiązanych z wpływem danego produktu na środowisko z jednej strony, a z drugiej - przekonać odbiorcę-klienta, że jednostka dba o środowisko naturalne. Rachunek ELCC staje się zatem uzupełnieniem zarówno tradycyjnego rachunku kosztów cyklu życia, jak i techniki LCA, przy jednoczesnym byciu elementem ekomarketingu. W artykule wykorzystano takie metody badawcze, jak analiza literatury przedmiotu, ankiety oraz metoda indukcji i dedukcji.

Słowa kluczowe: ekomarketing, ELCC, zielona rachunkowość.

Summary: Most entities implement a specific cost accounting system. It is intended to be tailored to the needs of the enterprise, enabling decision-making at both operational and strategic levels by management. However, in practice, many units design and implement it according to current and future needs, not taking into consideration ecological and environmental customer expectations. This article aims to present the possibility of using the so-called Environmental Life Cycle Costing (ELCC) in ecomarketing as well as survey results among enterprises in Lower Silesia related to such a combination, which may represent an ongoing development of science in the environmental protection. By implementing the ELCC, an information base about the costs and revenue associated with the environmental impact of the product can be obtained on the one hand and, on the other, the customer can be convinced that the unit cares about the natural environment. The ELCC account thus becomes a complement to the 
traditional life cycle costing of LCA as well as the LCA technique, while being an element of ecomarketing. The article uses research methods such as the analysis of the literature of the subject, surveys, and the method of induction and deduction.

Keywords: ecomarketing, ELCC, green accounting.

\section{Wstęp}

Ekologiczna ocena cyklu życia (Life Cycle Assessment - LCA) to pełna identyfikacja wpływów środowiskowych danego produktu na środowisko naturalne podczas pełnego cyklu jego życia. Powoduje to pomijanie kwestii zarówno ekonomicznych, jak i społecznych, co w znaczny sposób może ograniczać możliwość zastosowania jej w procesie podejmowania decyzji. Brak jest zatem analizy kosztów, a także rachunku efektywności. Wdrożenie środowiskowego rachunku kosztów cyklu życia (Environmental Life Cycle Costing - ELCC) umożliwi określenie występujących relacji między potencjalnym wpływem na środowisko danego produktu i kosztami jego produkcji oraz kosztami wpływu na to środowisko. Stać się on zatem może równocześnie ,aktywnym” elementem ekomarketingu.

\section{Koncepcja rachunku kosztów ELCC}

Najogólniej rzecz ujmując, rachunek ELCC to zestawienie wszystkich kosztów związanych z cyklem życia produktu, które są pokrywane bezpośrednio przez jeden lub więcej podmiotów w tymże cyklu życia (np. przez dostawcę, producenta, użytkownika lub konsumenta, a także osoby zaangażowane w fazie „the end of life") powiększone o koszty wpływu na środowisko. W literaturze przedmiotu sugeruje się, żeby wyżej wymienione koszty musiały odnosić się do rzeczywistych przepływów pieniężnych [Hunkeler i in. 2008]. Ogólne ramy środowiskowego rachunku kosztów cyklu życia opierają się na fizycznym cyklu życia produktu, co wymaga analizy co najmniej 5 głównych etapów. W momencie wdrożenia w przedsiębiorstwie mogą one podlegać uszczegółowieniu i doprecyzowaniu. Do tych etapów zalicza się:

- badanie i rozwój;

- produkcję;

- użytkowanie i konserwację;

- zarządzanie w fazie likwidacji i utylizacji.

Rachunek ELCC wprowadza w każdym z tych etapów, w przeciwieństwie do tradycyjnego LCC, tzw. koszty środowiskowe, czyli koszty gospodarczego korzystania ze środowiska. Można do nich zaliczyć m.in. opłaty za korzystanie ze środowiska, podatki ekologiczne, koszty kontroli emisji, koszty reklamy produktów ekologicznych, koszty odszkodowań z tytułu zanieczyszczenia środowiska, koszty leków i turnusów prozdrowotnych. W założeniach koncepcyjnych rachunku ELCC 
koszty te powinny być osobno ewidencjonowane w zespole $5 \mathrm{i}$ wyodrębniane w rachunku zysków i strat. W praktyce generuje to dodatkowe nakłady pracy, przekładające się na wzrost zatrudnienia i koszty z tym związane. Bardzo często wydzielenie kosztów środowiskowych z kosztów działalności operacyjnej odbywa się wyłącznie na podstawie szacowania i doświadczenia pracowników.

Rachunek ten analizuje również koszty od strony konsumenta, a także np. opłaty za składowanie odpadów i opłaty za recykling. Uwzględnia on wszystkie koszty środowiskowe powiększone o koszty zewnętrzne, potencjalne do wystąpienia w przyszłości [Hunkeler i in. 2008].

Środowiskowy rachunek kosztów cyklu życia został stworzony jako technika uzupełniająca analizę środowiskową LCA, co powinno przełożyć się na etap jego opracowywania - analogicznego do tej techniki.

LCA jest znormalizowaną metodą oceny wpływu danego produktu na środowisko oraz zużycia zasobów w całym cyklu jego życia [Ciambrone 1997]. Obejmuje ona swoim obszarem wydobycie surowców, wytwarzanie produktów, a następnie ich użytkowanie przez konsumentów końcowych, recykling, odzysk energii oraz ostateczne unieszkodliwienie pozostałego odpadu. Postępowanie w zakresie rachunku ELCC powinno być uzupełnieniem dla norm ISO 14040, ISO 14044, ISO 14045, ISO 14046 odnoszących się do cyklu życia produktu. Generalnie seria norm ISO 14000 odnosi się do systemów zarządzania środowiskowego, jednakże obejmuje ona swoim zakresem:

- audytowanie,

- etykietowanie środowiskowe,

- ocenę środowiskowych efektów działalności,

- ocenę cyklu życia,

- aspekty środowiskowe w projektowaniu i rozwoju wyrobów,

- komunikację środowiskową dotyczącą gazów cieplarnianych i zagadnień związanych ze zmianami klimatu,

- śladu wodnego i węglowego,

- kosztów środowiskowych [Polski Komitet Normalizacyjny 2015].

Normy ISO 14000 są opracowane tak, żeby nie mogły się wzajemnie wykluczać, a wręcz mają się uzupełniać. Z punktu widzenia jednostki, wdrożenie norm ,środowiskowych" może przynieść zarówno korzyści ekonomiczne, jak i środowiskowe, w głównej mierze dotyczące:

- ograniczenia i wykorzystania surowców naturalnych,

- zmniejszenia zużycia energii,

- poprawy efektywności procesów technologicznych,

- zmniejszenia ilości wytwarzanych odpadów;

- zmniejszenia ilości magazynowanych materiałów,

- obniżenia kosztów utylizacji i unieszkodliwiania odpadów,

- większego wykorzystanie zasobów odnawialnych,

- poprawy wizerunku firmy (ekomarketing) [Polski Komitet Normalizacyjny, 2015]. 
Na obecnym etapie rozwoju technologicznego produkcji wyrobów zaprezentowane poniżej etapy mogą stać się istotne dla realizacji techniki LCA z uwzględnieniem rachunku ELCC:

1. Określenie celu i zakresu definicji.

2. Zbieranie informacji.

3. Interpretacja i identyfikacji punktów krytycznych.

4. Analiza wrażliwości.

5. Podsumowanie[Hunkeler i in. 2008].

M. Rosund proponuje następujący proces tworzenia rachunku ELCC:

1. Zdefiniowanie problemu.

2. Zdefiniowanie elementów kosztów.

3. Modelowanie systemu.

4. Zbieranie danych.

5. Modelowanie profilu kosztów.

6. Ocena [Rausand 2001].

Analizy kosztów na bazie tego rachunku powinno się dokonywać w drugim etapie LCA, tj. podczas inwentaryzacji danych wejściowych (tworząc katalog materiałów i energii, można równocześnie określać ich koszty) i wyjściowych (przy uwzględnianiu ilości emisji i odpadów można np. w warunkach krajowych określić wysokość opłat za gospodarcze korzystanie ze środowiska) dla poszczególnych procesów jednostkowych i dla wybranej jednostki funkcjonalnej. Dzięki temu, „wejścia i wyjścia” zostaną zaprezentowane w mierniku pieniężnym [Hendrikson i in. 2006]. Uwzględniając dodatkowo możliwość określenia potencjalnego wpływu na środowisko, zarówno wytwórcy, jak i konsumenci mogą poszukiwać wyrobów o najmniejszym wpływie na środowisko (LCA) oraz najniższych kosztach cyklu życia (ELCC).

Można zatem zdefiniować rachunek ELCC jako sumę wszystkich kosztów ponoszonych podczas projektowania, budowy, produkcji, transportu, użytkowania wyrobów aż do ich końcowego składowania, gospodarczego wykorzystania i utylizacji, a także wpływu na środowisko naturalne oraz zdrowie społeczeństwa.

Jak już zasygnalizowano, środowiskowy rachunek kosztów cyklu życia różni się od założeń metody LCA, jeśli uwzględnić koszty, a nie tylko oddziaływanie na środowisko. Dzięki temu staje się on metodą zarządzania kosztami w ramach zrównoważonego rozwoju w celu oszacowania kosztów związanych z istnieniem danego produktu. Cel oraz zakres rachunku ELCC powinny zostać określone przed rozpoczęciem badań nad cyklem życia oraz wdrożeniem go w przedsiębiorstwie. Podstawowymi działaniami w celu zdefiniowania zakresu są:

- określenie kosztów całkowitych od strony zarówno podmiotu, jak i konsumentów;

- ocena konkurencyjności produktu - określenie kosztów konsumenta;

- sprawozdawczość, monitoring i aktywne określanie kosztów wewnątrz przedsiębiorstw; 
- osiągnięcie porozumienia na poziomie menedżerów, co do portfela produktów i określenia relacji ich z rachunkiem ELCC;

- identyfikacja możliwych alternatyw;

- identyfikacja kompromisu między aspektem ekonomicznym i środowiskowym;

- zdefiniowanie i określenie tzw. społecznej odpowiedzialności biznesu (CSR) wraz z oceną społecznych wpływów;

- identyfikacja potencjalnego przedsiębiorstwa i określenie kosztów w długim okresie, analiza potencjalnych korzyści ekonomicznych dla konsumentów, na etapie EOL (End-Of-Live) wpływu na środowisko i zagrożeń społecznych;

- definiowanie powiązań pomiędzy poszczególnymi kryteriami (na kosztów wewnętrznych w porównaniu z zewnętrznymi);

- definiowanie optymalnego cyklu życia uwzględniającego różnego rodzaju zmiany, np. systemów zakupu materiałów [Hunkeler i in. 2008].

Jako formułę obliczeniową dla ELCC przyjmuje się następujący wzór

$$
E L C C=C_{i c}+C_{i n}+C_{e}+C_{o}+C_{m}+C_{s}+C_{s}+C_{e n v}+C_{d},
$$

gdzie: $C_{i c}$ - wstępne koszty inwestycyjne, $C_{i n}$ - koszty instalacji, $C_{e}$ - koszty energii, $C_{o}$ - koszty operacyjne, $C_{m}$ - koszty konserwacji i napraw, $C_{s}$ - koszty przerw w eksploatacji i strat produkcyjnych, $C_{e n v}$ - koszty środowiskowe, $C_{d}$ - koszty utylizacji, likwidacji, rekultywacji itp. [Kowalski i in. 2007].

Jest to formuła wyjściowa, która powinna podlegać modyfikacji indywidualnie przez każdy podmiot do danego produktu.

\section{Ekomarketing}

Przedsiębiorstwa chcące wdrożyć strategie związane z szeroko rozumianym zarządzaniem środowiskowym powinny zwrócić szczególną uwagę na swojego odbiorcę, tzn. na to, jaki poziom świadomości ekologicznej reprezentuje. Umożliwi to zbudowanie odpowiednich relacji na linii firma-klient, co może stać się sposobem na osiągnięcie przewagi konkurencyjnej na rynku. Taka komunikacja ze świadomymi ekologicznie nabywcami, którzy oceniają przedsiębiorstwo i jego produktu przez pryzmat proekologicznej orientacji, wdrożenia koncepcji zrównoważonego rozwoju, działań na rzecz środowiska, może przebiegać odmiennie niż w tradycyjny sposób.

Ekomarketing jest jednym $\mathrm{z}$ aspektów koncepcji marketingu społecznego. Polega on na wkomponowaniu w system działań marketingowych zasad ekorozwoju. W literaturze przedmiotu można wyróżnić następujące podsystemy ekomarketingu:

- marketing ekorozwoju - zorientowany na świadomość klienta;

- marketing ekodobra - zorientowany na dobro, w tym marketing ekoproduktu i marketing ekousługi;

- marketing ekofirmy - zorientowany na organizację [Jabłoński 2001]. 
Najprostsza definicja ekomarketingu odnosi się do aspektu działań marketingowych zmierzających do produkcji i promocji produktów i usług nieszkodliwych dla środowiska naturalnego [Penc 1998]. Przedsiębiorstwo, które zdecyduje się na wdrożenie ekomarketingu, może przyjąć jedną z następujących strategii rynkowych:

- pasywną - przestrzeganie niezbędnych wymogów środowiskowych, tak aby nie narażać się na kary lub utratę dobrego wizerunku;

- defensywną - stopniowe wycofywanie z rynku produktów niespełniających norm ekologicznych, częściowa rezygnacja $\mathrm{z}$ technologii nieodpowiadających kryteriom ekologicznym, modyfikacja proekologicznych procesów produkcyjnych i usprawnień organizacji produkcji;

- innowacyjną - ekologizacja procesów produkcyjnych i produktów (np. wdrażanie tzw. czystych technologii, wykorzystanie odpadów jako surowców wtórnych);

- ofensywną - czysta produkcja, rozwój ekoproduktów, proekologiczna struktura i styl zarządzania [Kulas, Kusztal 2000].

W praktyce bardzo często występuje mieszanka powyższych strategii.

Wdrażając ten rodzaj marketingu w przedsiębiorstwach, nie można zapomnieć o wykorzystaniu tzw. znaków ekologicznych, które mogą być przyznawane przez różne instytucje państwowe, stowarzyszenia, fundacje, prywatne inicjatywy oraz producentów. Rada Unii Europejskiej opracowała standardy regulujące przyznawanie ekoznaków i wprowadziła w roku 1992 wspólny znak ekologiczny w postaci stylizowanej margerytki z 12 gwiazdkami. EU Ecolabel jest najważniejszym wyróżnieniem przyznawanym wyrobom spełniającym wysokie normy środowiskowe na terenie Unii Europejskiej. Ma on zachęcić przedsiębiorców działających na terytorium Wspólnoty do produkowania wyrobów bądź oferowania usług bardziej przyjaznych środowisku, a także informować odbiorcę, że produkty nie są szkodliwe dla środowiska i spełniają określone kryteria unijne. Kryteria te bazują na tzw. efektywności ekologicznej produktów z uwzględnieniem całego cyklu ich życia. Obejmują bieżące cele strategiczne Wspólnoty w dziedzinie ochrony środowiska, a także osiągnięcia naukowe, uwzględniając przede wszystkim:

- oddziaływanie produktu na środowisko (na klimat, biosferę, zużycie energii i zasobów, odpady, emisje gazów do środowiska);

- zastępowanie substancji niebezpiecznych substancjami przyjaznymi dla środowiska naturalnego;

- recykling produktów;

- korzyści i obciążenia dla środowiska z uwzględnieniem zdrowia i bezpieczeństwa odbiorców w każdym etapie cyklu życia danego produktu;

- aspekty społeczne i etyczne;

- kryteria ustanowione dla innych znaków środowiskowych;

- ograniczanie badań na zwierzętach;

- efektywne użytkowanie produktów opatrzonych znakiem EU Ecolabel [Tkaczyk 2010]. 
Równocześnie Międzynarodowa Organizacja Standaryzacyjna (ISO) opracowała w 1994 roku trzy kategorie znaków ekologicznych: typu I, typu II oraz typu III, ujmując wytyczne dla nich w 4 normach z serii ISO 14000. Etykiety I typu są przyznawane zgodnie z normą produktom, spełniającym zestaw z góry narzuconych wymagań i są pożądane w obrębie konkretnej kategorii produktów. Są one dobrowolne i mają na celu zmniejszenie wpływów produkcji produktów na środowisko na podstawie identyfikacji określonych kryteriów środowiskowych. Etykietowania II typu odnosi się wyłącznie do jednego aspektu produktu, który spełnia 18 wymagań, które powinny być m.in.:

1) istotne dla danego produktu i stosowane tylko we właściwym kontekście lub otoczeniu;

2) przedstawione w sposób, który jasno wskazuje, czy stwierdzenie odnosi się do całego produktu, czy tylko do składnika produktu lub opakowania;

3) specyficzne dla aspektu środowiskowego, będącego przedmiotem stwierdzenia;

4) prawdziwe w odniesieniu do produktu końcowego oraz uwzględniać istotne aspekty cyklu życia produktu;

5) odnoszone tylko do aspektu środowiskowego, który albo istnieje, albo może się pojawić w cyklu życia produktu;

6) prezentowane w taki sposób, żeby oczywista była konieczność łącznego czytania stwierdzenia i oświadczenia wyjaśniającego;

7) podawać i wyjaśniać podstawę porównania;

8) prezentowane w sposób, który wywoła u nabywców wrażenie, że stwierdzenie jest oparte na ostatniej modyfikacji produktu lub procesu;

9) oceniane ponownie i uaktualniane w związku ze zmianami w technologii lub innymi zmianami, które mogą wpłynąć na dokładność stwierdzenia;

10) istotne dla obszaru, na którym występują odpowiednie wpływy na środowisko [PN-EN ISO 14021:2016-06].

Deklaracje środowiskowe III typu to wyrażone ilościowo dane środowiskowe dotyczące cyklu życia produktu, oparte na procedurach badania cyklu życia produktu w metodzie LCA.

Przygotowując zatem informacje o produktach, firmy powinny zwrócić uwagę na eksponowanie w reklamie, promocji oraz na opakowaniach informacji o przyjaznej środowisku produkcji, wykorzystaniu ,zielonych” materiałów, wpływie produkcji na środowisko opakowań. Równocześnie starać się o jak największą liczbę uznanych ekoznaków z jednej strony, a z drugiej - przedstawiać wszelkie sprawozdania i raporty środowiskowe, finansowe i zrównoważonego rozwoju, w których będą informacje potwierdzające stosowaną politykę i produkcję proekologiczną.

Można zaproponować wręcz tezę, że ekomarketing jest namacalnym narzędziem polityki zrównoważonego rozwoju i społecznej odpowiedzialności biznesu. Umożliwia on przeorientowanie tradycyjnego myślenia w przedsiębiorstwach $\mathrm{w}$ myślenie ukierunkowane na rozpoznawanie i zaspokajanie „ekologicznych” potrzeb 
konsumentów, a także wdrażanie „zielonych” rozwiązań produkcyjnych. W tym celu przedsiębiorstwa powinny wdrażać takie techniki, jak Life Cycle Analysis, a szczególnie proekologiczną kalkulację kosztów wytwarzanych produktów, czyli Environmental Life Cycle Costing. Dzięki takiemu podejściu działania inspirowane ekomarketingiem mogą wspomóc budowanie więzi z konsumentem, poprawić wizerunek firmy (firma postrzegana jako etyczna, promująca wartości ekologiczne), a także wykreować produkt odpowiadający ekologicznym potrzebom klienta. Jak wynika z wytycznych dotyczących otrzymywania znaków ekologicznych, wszystkie one odnoszą się w swoich wymaganiach do oceny cyklu życia produktu w aspekcie środowiskowym przez pryzmat wpływu na nie jakościowo i ilościowo, w tym w przeliczeniu na jednostkę pieniężną. To możliwe jest dzięki zastosowaniu środowiskowego rachunku kosztów cyklu życia (ELCC).

\section{Wyniki badań}

W okresie styczeń-kwiecień 2017 r. drogą elektroniczną przeprowadzono kwestionariusz ankietowy wśród podmiotów z przewagą polskiego kapitału z branży produkcyjnej na Dolnym Śląsku, zaliczanych do sektora MMŚP. Otrzymano 81 wypełnionych ankiet, które zawierały następujące pytania:

1. Czy w przedsiębiorstwie stosowany jest ekomarketing?

2. Czy znają Państwo założenia środowiskowego rachunku kosztów cyklu życia (ELCC)?

3. Czy mają Państwo wdrożony rachunek ELCC?

4. Czy znając założenia rachunku ELCC, wdrożą go Państwo w przedsiębiorstwie?

5. Czy wdrożenie rachunku ELCC poprawi działania marketingowe Państwa przedsiębiorstwa?

6. Czy wdrażając rachunek ELCC, można spodziewać się poprawy wizerunku firmy wśród klientów?

Otrzymane wyniki badań zaprezentowano na rys. 1. W większości ankietowanych przedsiębiorstw nie ma zarówno stosowanego ekomarketingu, jak i wdrożonego rachunku ELCC. Odpowiednio 20\% badanych jednostek wykorzystuje ekomarketing, a 5\% rachunek ELCC . Założenia środowiskowego rachunku kosztów cyklu życia znane są tylko $15 \%$ badanych firm. Interesujące jest zestawienie odpowiedzi na pytania 4,5 i 6 . Z jednej strony przedsiębiorstwa dostrzegają znaczną poprawę działań marketingowych i wizerunku firmy (odpowiednio 30\% i 50\% badanych podmiotów), a z drugiej nie planują go wdrożyć. Tylko $10 \%$ respondentów opowiada się za implikacją systemu. Najprawdopodobniej związane jest to z tym, że przedsiębiorcy, po pierwsze, nie są zainteresowani zwiększaniem kosztów w aspekcie bieżącym, kiedy ewentualne korzyści mogą pojawić się po kilku okresach, po drugie - strachem przed wdrożeniem „czegoś nowego”, po trzecie zaś, nie widząc tego u konkurencji, nie zamierzają wychodzić przed szereg. Jest oto 


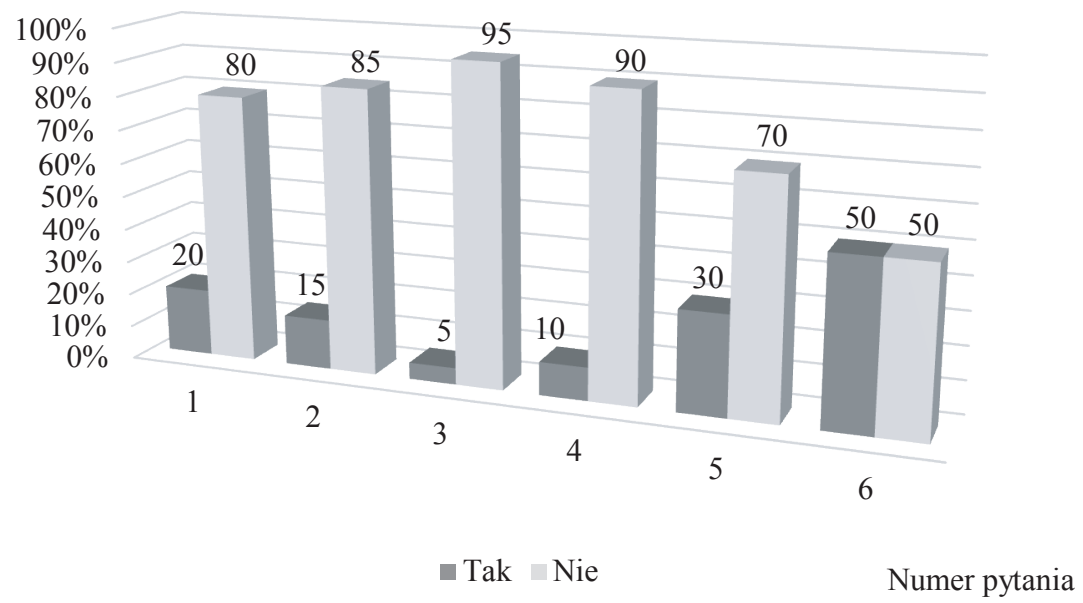

Rys. 1. Wyniki ankiety dotyczącej ekomarketingu i rachunku ELCC

Źródło: opracowanie własne.

o tyle dziwne, że w ciągle zmieniającym się świecie, przewagę konkurencyjną buduje się na innowacjach i na stosowaniu innowacyjnych rozwiązań, nawet w sferze finansowo-księgowej.

\section{Zakończenie}

Nowocześnie zarządzane przedsiębiorstwa nie powinny skupiać się wyłącznie na standardowych systemach zarządzania, które nie spełniają oczekiwań światowej polityki zrównoważonego rozwoju uwzględniającej w coraz szerszym zakresie ochronę środowiska. Obecnie należy rozpatrywać produkt, nie tylko jako konkretny wyrób, lecz jako proces jego tworzenia i wpływania na środowisko naturalne. Pełne uzupełnienie techniki LCA ma miejsce, kiedy zastosuje się także rachunek ELCC. Zapewnia to trwałe połączenie obu tych działań w aspekcie środowiskowym i ekonomicznym, co przełożyć się może na efektywność ekomarketingu, począwszy od projektowania procesów technologicznych, przez przyjazne dla środowiska decyzje zarządcze w kierunku racjonalnego wykorzystania wewnętrznych zasobów podmiotu i optymalizacji kompromisów między ochroną środowiska, aspektami gospodarczymi a biznesowymi. Można podsumować, że zarówno LCA, ELCC, jak i ekomarketing to uzupełniające się elementy polityki zrównoważonego rozwoju w aspekcie konsumpcji oraz produkcji. 


\section{Literatura}

Ciambrone D.F., 1997, Environmental Life Cycle Analysis, Lewis Publisher, New York, s. 6-9.

Hendrikson C.T., Lave L.B., Matthews H.S., 2006, Environmental Life Cycle Assessment of Goods and Services. An Input and Output Approach, RFF Washington, s. 10.

Hunkeler D., Lichtenvort K., Rebitzer G., 2008, Environmental Life Cycle Costing, CRC Press SETAC, s. 9-16.

Jabłoński J., 2001, Zarzadzanie środowiskowe jako warunek ekologizacji przedsiębiorstwa, Wydawnictwo Politechniki Poznańskiej, Poznań.

Kowalski Z., Kulczycka J., Góralczyk M., 2007, Ekologiczna ocena cyklu życia procesów wytwórczych, Wydawnictwa Naukowe PWN, Warszawa, s. 174.

Kulas I., Kusztal J., 2000, Zarządzanie środowiskiem w przedsiębiorstwie, Wydawnictwo Naukowe PWN, Warszawa.

Penc J., 1998, Strategie zarządzania Agencja Wydawnicza Placet, Warszawa.

PN-EN ISO 14021:2016-06 - PKN, Warszawa.

Polski Komitet Normalizacyjny, 2015.

Rausand M., 2001, Life Cycle Cost, NTNU, Trondheim.

Tkaczyk J., 2010, Oznakowania ekologiczne - nowe regulacje prawne, Przemysł. Środowisko. Jakość. Zarządzanie, 2(15). 